\title{
Determination of Dosage Reference (RfD) of Mercury Based on NOAEL and Characteristics of Workers in the Area of Unlicensed Gold Mining (PETI) Maluku Province Indonesia
}

\author{
Vaninda Eka Pridianata ${ }^{1}$, Abdul Rohim Tualeka ${ }^{1}$, Bacrudin Lain ${ }^{2}$, Pudji Rahmawati ${ }^{3}$, Syamsiar S Russeng $^{4}$, \\ Atjo Wahyu ${ }^{4}$, Ahsan ${ }^{5}$ \\ ${ }^{1}$ Department of Occupational Health and Safety, Faculty of Public Health, Airlangga University, 60155 \\ Surabaya, East Java, Indonesia; ${ }^{2}$ Department of Environmental Health, Health, Health Polytechnic \\ Ministry of Health Maluku, 97233 Negeri Lama, Ambon, Indonesia; ${ }^{3}$ Department of Development of \\ Islamic Society, State Islamic University Sunan Ampel, Surabaya, Indonesia; ${ }^{4}$ Department of Occupational \\ Health and Safety, Faculty of Public Health, Hassanuddin University, Makassar, Indonesia; ${ }^{5}$ Faculty of \\ Nurse, University of Brawijaya, Malang, Indonesia
}

\begin{abstract}
Mercury (Hydrargyrum $/ \mathrm{Hg}$ ) is one of the metals that are hazardous and toxic (B3), liquid, silver whitecolored, and easily evaporate at room temperature. In Indonesia, mercury is one of the environmental contaminants caused by illegal gold mining or Unlicensed Gold Mining (PETI). This study aims to determine the reference dose (RfD) of mercury in accordance with the characteristics of workers in Indonesia in order to be able to calculate and predict the risks to their health. This is an observational research by using a dose response approach and NOAEL in experimental animal of white mice (Rattus novergicus). The subjects in this study were the illegal mining workers in Kayeli Village. The sample used was 67 workers, while the object of this research was the concentration of mercury in wells water and Polymesoda eros shells which are frequently consumed by workers.

Mercury concentration in drinking water in the area of illegal Gold Mining (PETI) was still within safe limits for consumption of $0,0005 \mathrm{mg} / \mathrm{l}$, while the mercury concentration in Polymesoda erosa shells was not safe for consumption by $0.756 \mathrm{mg} / \mathrm{kg}$. Safe daily exposure dose of mercury in Kayeli Village Gold illegal mining area is $0,033 \mathrm{mg} / \mathrm{kg}$ with a NOAEL value of mercury of $0.23 \mathrm{mg} / \mathrm{kg}$. The RfD value can be used as a reference in predicting the risks to the health of workers in the area of Illegal Gold Mining (PETI) in Maluku Province of Indonesia.
\end{abstract}

Keywords: Mercury (Hg), Gold Mining, Reference of Doses (RfD), Workers

\section{Introduction}

According to WHO, mercury is a metal element that is formed naturally and is classified into 3 main groups of liquid and gas, inorganic mercury $\left(\mathrm{Hg}^{1+}\right)$ such as

\section{Coresponding Author:}

Abdul Rohim Tualeka

Department of Occupational Health and Safety, Faculty of Public Health, Airlangga University, 60155

Surabaya, East Java, Indonesia

Phone: +62 81333519732

Email: abdul-r-t@fkm.unair.ac.id mercury chloride, mercury acetate, mercury sulfide, and organic mercury $\left(\mathrm{Hg}^{2+) .1}\right.$ In Indonesia, mercury is one of the environment contaminants caused by illegal gold mining (PETI). One of the provinces in Indonesia with an increase in mobility and population migration due to gold mining activities is Maluku Province, Kayeli Village, Buru Regency. ${ }^{2}$ Contaminants mercury in the area is caused by the amalgamation method used by workers in an effort to bin gold metal from ore and tailings waste results. ${ }^{3}$ Without prevention and control, exposure to mercury can cause health impacts. In general, elemental and methylmercury mercury is very toxic and can affect central and peripheral nervous system, whereas organic 
mercury has an impact on kidney disorders and irritation of the eyes, skin and digestive tract. ${ }^{4}$ Health problems due to exposure to mercury can occur after various forms of mercury are inhaled, swallowed, or even absorbed by the body. ${ }^{5}$ Based on research conducted by Hasyimi et al (2014), gold mining in Kayeli Village has a negative impact on public health in the form of diseases that have never previously reported. ${ }^{2}$

Reference of dose (RfD) is a safe concentration of mercury recommended for humans. In several studies, Indonesia still uses the reference results of $\mathrm{RfD}$ in America and Europe, thus, it cannot be used as a reference in determining and predicting safe risks for the health of Indonesian workers. Health risk analysis in the Kayeli Village Gold Permit (PETI) area has been carried out in Lain et al. (2016) and the dose reference value (RfD) of mercury was $0.042 \mathrm{mg} / \mathrm{kg} /$ day, which is the US EPA reference dose. ${ }^{6}$ In addition, the determination of the mercury dose reference in Pahruddin's (2017) ${ }^{7}$ study also uses RfD as determined by USEPA (1997) of $0.0003 \mathrm{mg} / \mathrm{kg}{ }^{8}$ In this study, RfD was obtained based on the principle of dose response and toxicity test for determining the highest dose without causing effects on experimental animals or NOAEL. Toxicity test carried out by using experimental characteristics of Indonesian white mice (Rattus novergicus) and workers in the illegal mining area (PETI) of Kayeli Village.

The research to be carried out in this article is to determine RfD of mercury by using the characteristics of experimental animals and workers in the area of illegal Gold Mining (PETI) Maluku Province Indonesia. The purpose of this article is to calculate and predict the risks to the health of the right gold mining workers. The risk estimates for the health of the right workers in Kayeli Village can determine appropriate control and prevention efforts to overcome the effects of existing mercury pollution and can be used as material for decision-making by the parties concerned, both the regional government and the environment and health in Indonesia.

\section{Material and Method}

This study aims to determine the value of RfD as the determination of safe limits of toxin dosage for workers with non reactive research using the dose response approach and NOAEL. ${ }^{1}$ The subject of this study is the population of Kayeli Village as many as 558 people with a sample of 67 people. The object of this study consisted of samples of dug well water and samples of shellfish that were often consumed by the people of Kayeli Village. Data analysis was performed by using descriptive analysis on each research variable to describe the characteristics of each sample and quantitative analysis in determining RfD of toxins for workers. Determination of RfD for workers is determined by calculation by formula?

$$
\mathrm{R} f \mathrm{D}=\mathrm{NOAEL} \frac{\text { Animal Km }}{\text { Human Km }}
$$

\section{Result}

A. Characteristics of Experimental Animals, Surface Area of Experimental Animal, and Surface Area of Experimental Animal: Toxicity tests on experimental animals are based on the theory of extrapolation from animal testing data to humans. ${ }^{9}$ The following is the formula used in calculating the surface area of the tested animal body:

Animal BSA $=0.09 \times \mathrm{W}^{0.67}$

Where:

BSA : Body Surface Area $\left(\mathrm{m}^{2}\right)$

W : Weight $(\mathrm{kg})$

Table 1: Characteristics of Experimental Animals, Surface Area of Experimental Animals, and Surface Area of Experimental Animal Bodies

\begin{tabular}{|c|c|c|}
\hline $\begin{array}{c}\text { Experimental } \\
\text { animal }\end{array}$ & W (kg) & BSA (m $\left.\mathbf{m}^{\mathbf{}}\right)$ \\
\hline 1 & 0.1405 & 0.024165 \\
\hline 2 & 0.1405 & 0.024165 \\
\hline 3 & 0.1410 & 0.024223 \\
\hline 4 & 0.1410 & 0.024223 \\
\hline 5 & 0.1395 & 0.024050 \\
\hline 6 & 0.1415 & 0.024165 \\
\hline
\end{tabular}

B. Characteristics, Surface Area, and Body Surface Area of Experimental Animal: The characteristics of workers' body weight and body surface area of the worker are used in the analysis. Based on Table 2, workers' body weight ranged from $52 \mathrm{~kg}$ to $89 \mathrm{~kg}$ with an average weight of $70 \mathrm{~kg}$ and a median value of $71 \mathrm{~kg}$, the average height was $159 \mathrm{~cm}$.

The calculation of the average surface area of the worker's body is performed by using the following formula9: 


$$
\begin{aligned}
\text { Human BSA } & =\sqrt{\frac{\mathrm{W} \times h}{3600}} \\
& =\sqrt{\frac{71 \times 159}{3600}} \\
& =1.77\left(\mathrm{~m}^{2}\right)
\end{aligned}
$$

Where:

BSA : Body Surface Area $\left(\mathrm{m}^{2}\right)$

W : Weight $(\mathrm{kg})$

$\mathrm{h}:$ Height $(\mathrm{cm})$

Table 2: Workers' Characteristics and Body Surface Area

\begin{tabular}{|c|c|c|c|}
\hline $\begin{array}{c}\text { Number of } \\
\text { sample }\end{array}$ & $\begin{array}{c}\text { W } \\
(\mathbf{k g})\end{array}$ & $\begin{array}{c}\mathbf{h} \\
\mathbf{( c m )}\end{array}$ & $\begin{array}{c}\text { BSA } \\
\left.\mathbf{( m}^{\mathbf{2}}\right)\end{array}$ \\
\hline 67 & 71 & 159 & 1.77 \\
\hline
\end{tabular}

Based on the distribution of Table 2, the average body surface area of workers in Illegal mining of Kayeli Village is $1.77 \mathrm{~m}^{2}$.

\section{Mercury Concentration}

\section{Concentration of Mercury in Drinking}

Water: Measurement of mercury concentrations in drinking water was carried out in 3 excavated wells consumed by the community who live closer to the amalgamation process. Based on the distribution of Table 3, the result of laboratory measurements at 3 points of the dug wells of Kayeli Village shows an average mercury concentration of $0.0005 \mathrm{mg} / \mathrm{l}$.

Table 3: Concentration of Mercury in Drinking Water of Kayeli Village

\begin{tabular}{|c|c|}
\hline Location & $\mathbf{C}(\mathbf{m g} / \mathbf{L})$ \\
\hline 1 & 0.0005 \\
\hline 2 & 0.0005 \\
\hline 3 & 0.0005 \\
\hline Average & 0.0005 \\
\hline
\end{tabular}

2. Concentration of Mercury in Polymesoda erosa shells: Measurement of mercury concentration in Polymesoda erosa shells was carried out at 3 tailings disposal sites directly to the beach and each location was measured 3 points, so that the total sample of shells measured was 9 points. In gold mining, the tailings resulting from gold mining contain inert minerals (inactive) and one or more toxic hazardous materials including mercury. ${ }^{3}$

\begin{tabular}{|c|c|}
\hline Location & $\mathrm{C}(\mathrm{mg} / \mathrm{kg})$ \\
\hline 1.1 & 0.3438 \\
\hline 1.2 & 0.5481 \\
\hline 1.3 & 0.6133 \\
\hline 2.1 & 0.3563 \\
\hline 2.2 & 0.4929 \\
\hline 2.3 & 0.5955 \\
\hline 3.1 & 0.3930 \\
\hline 3.2 & 0.7244 \\
\hline 3.3 & 2.7406 \\
\hline Average & 0.756 \\
\hline
\end{tabular}

Table 4: Mercury Concentration in Polymesoda erosa Shells

Based on Table 4, the result of laboratory test of mercury concentration in the lowest shells at 1.1 was $0.3438 \mathrm{mg} / \mathrm{kg}$, while the highest mercury concentration in shells at location 3.3 was $2.7406 \mathrm{mg} / \mathrm{kg}$. The average value of mercury concentration in Polymesoda erosa shell was $0.756 \mathrm{mg} / \mathrm{kg}$.

\section{Animal Km and Human Km}

1. Animal Km: Calculation of Animal Km is one of the first steps prior to determining the safe dose limit for toxins for workers. ${ }^{9}$ Animal Km can be calculated by using the formula below:

Animal $\mathrm{Km}=\frac{\mathrm{W} \text { animal }}{\text { BSA animal }}$

Where:

Animal $\mathrm{Km}: \mathrm{Km}$ factor

W : Weight $(\mathrm{kg})$

BSA Animal : Body surface area $\left(\mathrm{m}^{2}\right)$

Table 5: Results of Calculation of Animal $\mathrm{Km}$ in Experimental Animals (White Mice)

\begin{tabular}{|c|c|c|c|}
\hline $\begin{array}{c}\text { Experi-mental } \\
\text { animal (white mice) }\end{array}$ & $\begin{array}{c}\mathbf{W} \\
(\mathbf{k g})\end{array}$ & $\begin{array}{c}\text { BSA } \\
\left.\mathbf{( m}^{\mathbf{2}}\right)\end{array}$ & $\begin{array}{c}\text { Animal Km } \\
\mathbf{( W / B S A )}\end{array}$ \\
\hline 1 & 0.1405 & 0.024165 & 5.814194082 \\
\hline 2 & 0.1405 & 0.024165 & 5.814194082 \\
\hline 3 & 0.1410 & 0.024223 & 5.820914007 \\
\hline 4 & 0.1410 & 0.024223 & 5.820914007 \\
\hline 5 & 0.1395 & 0.024050 & 5.8004158 \\
\hline 6 & 0.1415 & 0.024165 & 5.855576247 \\
\hline Average & 0.1407 & 0.024165 & 5.82 \\
\hline \multicolumn{2}{|r}{} \\
\end{tabular}


Based on Table 5, the calculation of the average value of Animal $\mathrm{Km}$ in white mice is 5.82 .

2. Human Km: The Human $\mathrm{Km}$ calculation is the next calculation that must be done before determining the safe dose limit for toxins for workers. ${ }^{9}$ Human $\mathrm{Km}$ can be calculated using the formula below:

Human $\mathrm{Km}=\frac{\mathrm{W} \text { human }}{\text { BSA human }}$

Where:

Human $\mathrm{Km}: \mathrm{Km}$ factor

$\mathrm{W}$ : Weight $(\mathrm{kg})$

BSA Animal : Workers' body surface area $\left(\mathrm{m}^{2}\right)$

Table 6: Average Human Km Calculation Results

\begin{tabular}{|c|c|c|c|}
\hline $\begin{array}{c}\text { Number of } \\
\text { sample }\end{array}$ & $\mathbf{W}(\mathbf{k g})$ & BSA $\left(\mathbf{m}^{2}\right)$ & $\begin{array}{c}\text { Human } \mathbf{~ K m} \\
\text { (W/BSA) }\end{array}$ \\
\hline 67 & 71 & 1.77 & 40.11 \\
\hline
\end{tabular}

Based on Table 6, the results of calculating the average Human Km value of workers in the area of Unlicensed Gold Mining (PETI) is 40.11 .

E. NOAEL (No Observed Adverse Effect Level): NOAEL is one of the information that can be used to estimate the safety/risk of chemicals for the human body and also become one of the environmental quality criteria main indicators. ${ }^{9}$ According to $\mathrm{EPA}^{10}$ and $\mathrm{WHO}^{1}$, NOAEL value of mercury is $0.23 \mathrm{mg} / \mathrm{kg}$.

F. Reference of Dose (RfD): Mercury exposure through the ingestion pathway, the type of safe dose determination for toxins for the body of the worker uses RfD. ${ }^{11}$ Determination of RfD can be calculated using the formula below'

$\mathrm{R} f \mathrm{D}=\mathrm{NOAL} \frac{\text { Animal } \mathrm{Km}}{\text { Human } \mathrm{Km}}$

Where:

$\mathrm{RfD}$ : Reference of Dose $(\mathrm{mg} / \mathrm{kg})$

Animal Km : Km factor (Rattus norvegicus)

Human $\mathrm{Km}: \mathrm{Km}$ factor

Based on the formula, mercury exposure RfD is $0.033 \mathrm{mg} / \mathrm{kg}$ through the following calculations:

$$
\begin{aligned}
\mathrm{R} f \mathrm{D} & =0.23 \frac{5.82}{40.11} \\
& =0.033 \mathrm{mg} / \mathrm{kg}
\end{aligned}
$$

\section{Discussion}

Mercury exposure to workers in the illegal Gold Mining Area in Kayeli Village occurs through ingestion pathways. Based on observations, the average mercury concentration in drinking water in the area of Unlicensed Gold Mining (PETI) is $0.0005 \mathrm{mg} / \mathrm{l}$ and is still below the maximum value of mercury permitted and determined by Minister of Health Regulation No.492 of $2010^{12}$ concerning Drinking Water Quality Requirements and $\mathrm{WHO}^{13}$ of $0,001 \mathrm{mg} / \mathrm{l}$ in The Guidelines for Drinkingwater Quality. The average mercury concentration in Polymesoda erosa shells in is $0.756 \mathrm{mg} / \mathrm{kg}$ and exceeds the maximum limit value of $0.01 \mathrm{mg} / \mathrm{kg}^{4}$ and the minimum risk level value is $0.002 \mathrm{mg} / \mathrm{kg}$ determined by Agency for Toxic Subtances and Disease Register. ${ }^{14}$

The value of NOAEL is toxicity test for determining the highest dose without causing any effects on experimental animals and is based on the theory of extrapolation of doses from experimental animals to humans. ${ }^{15}$ By determining the characteristics of workers in the area of Kayeli Illegal Mining (PETI), the average body weight is $71 \mathrm{~kg}$ and height is $159 \mathrm{~cm}$, NOAEL value of mercury is $0.23 \mathrm{mg} / \mathrm{kg} .{ }^{10}$ This value is lower than the NOAEL value of mercury obtained in the Branco study in 2017 is $10 \mathrm{mg} / \mathrm{kg}$ in a mother's hair. ${ }^{16}$ From the various NOAEL values obtained from several predetermined references, NOAEL is an experimentally determined dose and there is no statistically or biologically significant indication of the toxic effect in question. ${ }^{15}$

$\mathrm{RfD}$ is a non-carcinogenic quantitative toxicity in the form of estimates of daily exposure doses that are not expected to cause adverse health effects even though the exposure lasts for life. ${ }^{5}$ The mercury RfD value in the area of Unlicensed Gold Mining (PETI) in Kayeli Village is $0,033 \mathrm{mg} / \mathrm{kg}$. Mercury RfD value is bigger than the mercury RfD value set by USEPA $(1997)^{8}$ and has been used in Pahruddin's research (2017) ${ }^{7}$ at 0,0003 $\mathrm{mg} / \mathrm{kg}$. In addition, according to the Agency for Toxic Subtances and Disease Register the value of mercury RfD in Kayeli Village is also bigger than the ATSDR RfD value of $0,0004 \mathrm{mg} / \mathrm{kg} .{ }^{14} \mathrm{RfD}$ values obtained through NOAEL calculations and experimental toxicity tests are inversely proportional to $\mathrm{Km}$ factors in humans/workers. This is supported by Safitri's research (2015) which states that the greater a person's weight, the less likely the risk is to experience health problems because human 
body weight reflects a person's nutritional status. If a person's nutritional status is bad it can affect the decline in endurance. ${ }^{17}$ When the immune response decreases, there has been an effect or effect of a chemical/dangerous heavy metal in the body. The integrity of the immune system is needed to defend against microorganisms and toxic products produced. ${ }^{18}$

\section{Conclusion}

The concentration of mercury in drinking water contained in the wells digging in the area of Unlicensed Gold Mining (PETI) is still within safe limits for consumption by workers with an average mercury concentration of $0.0005 \mathrm{mg} / \mathrm{l}$, while the average value of mercury concentrations in Polymesoda erosa area shells Unlicensed Gold Mining (PETI) of $0.756 \mathrm{mg} / \mathrm{kg}$ is not safe for consumption by workers. If there is no attempt to control mercury concentrations in the shell intake per day, adverse health effects on workers in the Gmining area area of Kayeli Village can emerge. In addition, the daily exposure dose of mercury that is not expected to have a detrimental effect on health in the Kayeli Village Gold Permit area of $0,033 \mathrm{mg} / \mathrm{kg}$ with NOAEL value of mercury of $0.23 \mathrm{mg} / \mathrm{kg} .{ }^{10}$

\section{Recommendation}

Recommended control related to mercury exposure in the Kayeli Village Ilegal Gold Mining Area (PETI) is administrative controls in the form of actions to develop policies related to licensing gold mining activities in the area by the Kayeli Village government. If the policy is enforced and can be implemented properly, it can reduce mining activities that pollute the waters of the Kayeli Village. In addition, technical control in the form of handling mercury pollution can be carried out using the role of microorganisms or bioaccumulation, bioremediation and bioremoval processes.

Conflict of Interest: All authors have no conflicts of interest to declare

Source of Funding: This is an article about "Determination of Dosage Reference (RfD) of Mecury based NOAEL and Characteristics of Workers in Unlicensed Gold Mining Areas (PETI) Maluku Province, Indonesia" of Occupational Health and Safety Departement thas was supported by Faculty of Public Health, Airlangga University
Ethical Clearence: The study was approved by the institutional Ethical Board of the Public Health, Diponegoro University

\section{REFERENCES}

1. (WHO) WHO. Concise International Chemical Assessment Document 50 ELEMENTAL MERCURY AND INORGANIC MERCURY COMPOUNDS : HUMAN HEALTH ASPECTS. Geneva; 2003.

2. M. Hasyim, Yulianis Rahim B. Persepsi Jajaran Kesehatan Tentang Dampak Kegiatan Penambangan Emas di Kabupaten Buru Provinsi Maluku Tahun 2012. Ekol Kesehat. 2014;13:86-94.

3. Fahruddin. Pengelolaan Limbah Pertambangan Secara Biologis : Biological Management Mining Waste. Celebes Media Perkasa; 2018. 1-214 p.

4. Indonesia MKR. Peraturan Menteri Kesehatan Nomor 57 Tahun 2016 tentang Rencana Aksi Nasional Pengendalian Dampak Kesehatan Pajanan Merkuri Tahun 2016-2020. Indonesia; 2016. p. 16.

5. PL DJP dan. Pedoman Analisis Risiko Kesehatan Lingkungan (ARKL). Indonesia: Kementerian Kesehatan RI; 2012. 1-84 p.

6. Bacrudin Lain, Yusniar Hanani D. TJ. Analisis Risiko Kesehatan Lingkungan Pajanan Merkuri Pada Masyarakat di Area Pertambangan Emas Tanpa Izin (PETI) Desa Kayeli Kabupaten Buru Provinsi Maluku. Kesehat Masy. 2016;4:129-38.

7. Pahruddin M. Risiko Pajanan Logam Berat Pada Air Sungai. Kesehat Lingkung. 2017;14(1):525-32.

8. Compounds M. Mercury Study Report to Congress. Vol. V. United States; 1997.

9. Tualeka AR. Toksikologi Industri. Revisi Surabaya: Graha Ilmu Mulia; 2013.

10. (WHO) WHO. Summary Statement of Mercury [Internet]. Available from: http://www.who int/water_sanitation_health/dwq/chemicals/ mercurysumstatement.pdf?ua $=1$

11. Saputra AD. Hubungan Pajanan Partikel Debu Terhirup (PM10) Terhadap Keluhan Asma Pada Masyarakat Berisiko di Sekitar Terminal 
Antar Kota Provinsi (AKAP) Kota Palembang Tahun 2016. Universitas Islam Negeri Syarif Hidayatullah; 2017.

12. Indonesia MKR. Peraturan Menteri Kesehatan Republik Indonesia Nomor 492/MENKES/ PER/IV/2010 Tentang Persyaratan Kualitas Air Minum. Indonesia; 491/MENKES/PER/IV/2010, 2010. p. 1-9.

13. Rosihan Adhani H. Logam Berat Sekitar Manusia. Kholishotunnisa S, editor. Banjarmasin: Lambung Mangkurat University Press; 2017. 1-186 p.

14. (ATSDR) A for T and SDR. TOXICOLOGICAL PROFILE FOR MERCURY. Atlanta, Georgia; 1999.

15. Tualeka AR, Faradisha J, Maharja R. Determination of No-Observed-Adverse- Effect Level Ammonia in White Mice Through CD4 Expression. 2018;(December):1-9.
16. Branco V, Caito S, Farina M, Teixeira J, Carvalho C. Biomarkers of mercury toxicity : Past, present, and future trends. J Toxicol Environ Heal Part B [Internet]. 2017;00(00):1-36. Available from: http://dx.doi.org/10.1080/10937404.2017.1289834

17. Safitri FZ. Tingkat Efek Kesehatan Lingkungan Kandungan Logam Berat Kadmium (Cd) pada Kerang Hijau (Perma viridis) yang Dikonsumsi Masyarakat Kaliadem Muara Angke Jakarta Utara Tahun 2015. Universitas Islam Negeri Syarif Hidayatullah Jakarta; 2015.

18. Tualeka AR, Wibrata DA, Ahsan A, Rahmawati P, Russeng SS, Wahyu A. Determination of Highest Dose of Ammonia without Effect at Work Environment through the Expression of Interleukin-2 Cell in Rattus Novergicus. Maced J Med Sci. 2019;7(6):897-902. 